of immunotoxins would greatly diminish the number of virus particles released, over a period of time, into the circulation following the destruction of $\mathrm{CD}^{+}$cells. As a consequence of this reduced number of viral particles thus released, they could probably be neutralized effectively by the antibodies already present in the patient's blood. On the other hand, infusion of antiCD4 antibody alone (which by itself cannot attenuate the viral population) would release far greater numbers of viral particles. As a result, the neutralizing capacity of the circulating antibodies may be considerably reduced. The injection of antiviral antibodies to neutralize the virus would then be required. Because of the antigenic drift ${ }^{8}$ noted with this virus, extraneous infusion of anti-HTLV-III/LAV antibodies may not be particularly helpful in neutralizing the large pool of HTLVIII/LAV released by treatment with antiCD4 antibodies.

Thus the administration of immunotoxins in miniscule amounts (as RIPs act in a catalytic manner) might forestall the spread of AIDS virus. Moreover, as only a small proportion of $\mathrm{CD}^{+}$cells are infected by the virus' and as fresh peripheral blood lymphocytes of AIDS patients do not show the presence of viral DNA, there will probably be no necessity for immuneenhancing therapy with immunotoxins.

Avadhesha Surolia M.P. RAMPRASAD

Indian Institute of Science,

Molecular Biophysics Unit,

UGC Centre of Advanced Study, Bangalore 560012 , India

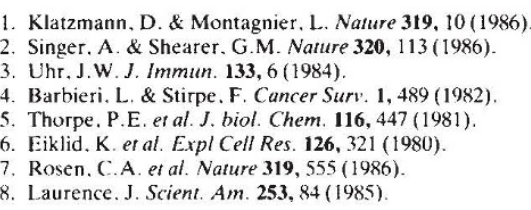

\section{Earthquake prediction and electric signals}

SIR-In a comment in News and Views P.W. Burton discussed our publications in Tectonophysics ${ }^{2}$ on the prediction of the epicentre and the magnitude of earthquakes within a time window of 7 to 115 hours, based on the monitoring of the simultaneous changes of the electric field of the Earth observed at a number of sites. Burton expressed doubts about the claimed connections between earthquakes and the precursor signals, especially during periods of high seismicity. Of course, there is a high probability of an earthquake occurring somewhere within the time window, but we have isolated a large number of events in both time and seismic region.

A recent case, with an exceedingly small probability of having been predicted by chance, illustrates our point. On 17
December 1985, we presented a prediction to the session of the Greek Special Committee on Earthquake Prediction, which was recently established by the Greek Ministry of Public Works and consists of geologists, seismologists and physicists. The electric signals allowed two solutions, one for an event of magnitude 4.8 in the sea to the south of Kalamata (southern continental Greece) and the other for a 5.2 mag event on the coast of Asia Minor near the island of Samos. Forty hours later a 5.2 mag event occurred within $150 \mathrm{~km}$ of the site expected from the second solution. As no earthquake with $M>4.7$ had occurred within the $75,000-\mathrm{km}^{2}$ area $36.7-40.0^{\circ} \mathrm{N}$ and $25.0-$ $27.5^{\circ} \mathrm{E}$ for at least the previous 14 months, the time-probability is smaller than $10^{-2}$. Obviously the probability of simultaneously predicting the time, epicentre and magnitude is appreciably smaller.

Another recent case is the following: On 29 March 1986 a 6.1 mag event occurred at $38.3^{\circ} \mathrm{N}-25.3^{\circ} \mathrm{E}$. Four days earlier the government had been officially informed of an impending $6.1 \mathrm{mag}$ earthquake. The error in the prediction of the epicentre was less than $50 \mathrm{~km}$.

P. VAROTSOS

K. Alexopoulos

K. Nomicos

Knossou 36, Ano Glyfada.

M. LAZARIDOU

16561 Athens, Greece

Burton. P.W. Nuture 315, 370-371 (1985)

Varotsos. P. \& Alexopoulos. K. Tectonophrsics 110, 73, 99 $(1984)$

\section{The stability of zoological nomenclature}

SIR-As one of those cast by Erzinclioglu and Unwin (Nature 320, 687; 1986) as "having a legalistic turn of mind", I would like to protest the spirit, as well as the content, of their letter which was intended to detail the inadequacies of the International Code of Zoological Nomenclature and to protest the "tyranny of the Commission".

First, the writers do not seem to understand the meaning of stability in the sense of the code. Stability has never been taken to mean that a name shall remain unchanged and unchangeable: the preamble of the Code states that, "All its [Code] provisions and recommendations are subservient to these ends [promoting stability and universality in the scientific names of animals] and none restricts the freedom of taxonomic thought or action." Further, the plenary powers of the Commission, defined in Article 79, outline the responsibility of the body to maintain stability and specifically refer to the suppression of a senior homonym as a potential option in assuring stability.

With regard to a few specific points raised by Erzinclioglu and Unwin, the
Code has, for several editions, made a clear distinction between the endings of names and the name of the taxon. Thus, changing the ending of a species name to agree with that of the genus in no way constitutes a change of names.

A similar observation, of course, applies to the authors' argument regarding elevation of subfamily groups to the family level. The reasoning behind the rules governing change of rank within the family-group seems altogether clear and I cannot imagine such a change could cause confusion.

In their lengthy summary of the change of species names for the medically important African fly Auchmeromyia luteola, or perhaps I should say $A$. senegalensis, the writers do not seem to be offended by the change in generic placement, which presumably occurred before their entry into the world of nomenclature, but only by the discovery of an obscure senior homonym and subsequent name replacement. Their irritation is misplaced and might better have been directed at the author(s) of Catalogue of the Diptera, who chose to offer a replacement name rather than to maintain the well-known name and refer the matter to the Commission. This option has existed for years and is the rational way to resolve this kind of problem and assure stability.

Erzinclioglu and Unwin seem particularly confused regarding the relationship between the rules of nomenclature and the classification of organisms. Adherence to the principles of cladism or, for that matter, "traditional" systematics have no bearing whatsoever on the value of the Code.

Finally, those of us who "mindlessly" adhere to the Code resent the notion that anarchy is the only sane alternative to felt weaknesses in the rules. There is, and always has been, the alternative of petition for change in the document. In my opinion the present Code constitutes an improvement, in some areas, over the previous edition. There remain very real problems regarding application of the rules to collective groups and ichnotaxa - problems that will probably never be resolved to everyone's satisfaction - but there is a mechanism within the rules to allow change to be proposed.

I find it ludicrous to consider the Commission as a group of hooded tyrants whose purpose it is to impose their arbitrary will upon the scientific community, from which, of course, they were elected. It may come as some consolation to Erzinclioglu and Unwin to note that by the act of expressing their interest in nomenclature, they have qualified themselves for nomination to election to the Commission.

Department of Geology.

RODNEY M. FELDMANN

Kent State University,

Kent, Ohio 44242, USA 